\title{
Comparison of the proteome of Mycobacterium tuberculosis strain H37Rv with clinical isolate CDC 1551
}

\author{
Joanna C. Betts, ${ }^{1}$ Paul Dodson, ${ }^{2}+$ Selwyn Quan, ${ }^{1} \neq$ Alan P. Lewis, ${ }^{2}$ \\ Pam J. Thomas, ${ }^{2} \mathbb{S}$ Ken Duncan ${ }^{1}$ and Ruth A. McAdam ${ }^{1}$
}

Author for correspondence: Joanna C. Betts. Tel: +44 1438 768138. Fax: +44 1438764898. e-mail: jb75084@glaxowellcome.co.uk

1 Immunopathology Unit ${ }^{1}$ and Protein Science Unit², Glaxo Wellcome Research and Development, Medicines Research Centre, Stevenage, Herts, SG1 2NY, UK

\begin{abstract}
The genome sequences of two virulent strains of Mycobacterium tuberculosis (H37Rv and CDC 1551) are now available. CDC 1551 is a recent clinical isolate and H37Rv is a commonly used lab strain which has been subject to in vitro passage. The two strains have been shown to display differing phenotypes both in vivo and in vitro. The proteome of the two strains grown in liquid culture were examined over time to determine whether there are any major differences between them at the protein level and the differences were compared to the genome data. Total cell lysates of the two strains were analysed by two-dimensional electrophoresis. Approximately 1750 protein spots were visualized by silver staining and the protein profiles of the two strains were found to be highly similar. Out of a total of 17 protein spot differences, seven were unique to CDC 1551 and three to H37Rv. Two further spots showed increased intensity in H37Rv, one spot showed differing vertical mobility between the strains and four showed differing spot intensities with time. Twelve of the spot differences were identified using mass spectrometry; however, no obvious association with phenotype could be deduced. When genome differences were analysed and related to the proteome differences, a mobility shift identified in the MoxR protein could be explained by a point mutation at the gene level. This proteome analysis reveals that, despite having been maintained under vastly different conditions, namely in vitro passage and in vivo transmission, these two strains have remained highly similar.
\end{abstract}

Keywords: mycobacteria, tuberculosis, proteome, two-dimensional gel electrophoresis, genome

\section{INTRODUCTION}

The complete genome sequence of Mycobacterium tuberculosis $\mathrm{H} 37 \mathrm{Rv}$ has recently been published (Cole et al., 1998). Although not yet totally complete, the sequence of a second strain, CDC 1551, a recent clinical

\footnotetext{
†Present address: Molecular Biology, AstraZeneca R\&D Charnwood, Bakewell Road, Loughborough LE11 5RH, UK.

$\ddagger$ Present address: Department of Molecular Biology and Microbiology, Tufts University, Boston, MA 02111, USA.

\Present address: Astex Technology, 250 Cambridge Science Park, Milton Road, Cambridge CB4 OWE, UK

Abbreviations: 2D, two-dimensional; BCG, bacille Calmette-Guérin; IPG, immobilized $\mathrm{pH}$ gradient; MALDI, matrix-assisted laser desorption-ionization; PGRS, polymorphic $\mathrm{G}+\mathrm{C}$ rich sequence; PE, Pro-Glu; PPE, Pro-ProGlu; TOF, time-of-flight.
}

isolate (Valway et al., 1998), has also been made publicly available via the internet (http://www.tigr.org/tdb/ $\mathrm{CMR} / \mathrm{gmt} / \mathrm{htmls} /$ SplashPage.html). The two genomes show $>99 \%$ identity at the nucleotide level (Delcher $e t$ al., 1999) but the strains display phenotypic differences which might be explained by changes at the proteinexpression level.

M. tuberculosis $\mathrm{H} 37 \mathrm{Rv}$ is the most commonly studied laboratory strain and was first isolated in 1905. Since this time it has been continually passaged and, as its virulence in humans is unknown, there have been concerns as to whether this may have led to attenuation of virulence (Jacobs et al., 1996). However, it has maintained virulence in animal models. In contrast, CDC 1551 is a recent clinical isolate which was responsible for an outbreak of $\mathrm{TB}$ in a rural area of the 
USA in 1995 (Valway et al., 1998). Due to the high rate of skin-test conversion that occurred and the large skintest response to purified protein derivative of tuberculin (PPD) of those infected, CDC 1551 was considered to be unusually infectious in man. In addition, evaluation of the growth of CDC 1551 in lungs of mice $20 \mathrm{~d}$ after aerosol infection gave 100 -fold higher numbers of bacilli compared to the numbers of bacilli isolated from the lungs of mice infected with the M. tuberculosis laboratory strain Erdman (Valway et al., 1998). As a result of these findings, CDC 1551 was assumed to be highly virulent and was selected for sequencing by the National Institutes of Health (Jacobs et al., 1996).

More recently, however, the growth of CDC 1551 has been compared to both $\mathrm{H} 37 \mathrm{Rv}$, the Erdman strain and two clinical isolates in a mouse aerosol infection model (Manca et al., 1999). These studies confirmed CDC 1551 replicates to higher number in mice than Erdman but showed it to have a comparable growth rate to H37Rv and the two additional recent clinical isolates. This study also found CDC 1551 induces granulomatous differentiation and high cytokine levels in the lungs of infected mice at an earlier time point than any of the other strains studied. When human monocytes were infected with CDC 1551, larger amounts of cytokines were produced than in monocytes infected with H37Rv, although there were similar numbers of intracellular organisms (Manca et al., 1999). It was therefore suggested that CDC 1551 is not more virulent but induces a more rapid and vigorous immune response (Manca et al., 1999). The two strains have also been compared in a rabbit inhalation model (Bishai et al., 1999) where it was shown that CDC 1551 has no greater ability either to induce visible pulmonary tubercles or to multiply within these tubercles.

Comparison of the proteome of strains may therefore explain some of these phenotypic differences and may shed light on the mechanism of survival of $M$. tuberculosis within the host. This information is crucial for the design of new anti-tubercular vaccines and drugs. Since the virulence of $M$. tuberculosis of $\mathrm{H} 37 \mathrm{Rv}$ in man is unknown, comparison of its proteome with that of a recent clinical isolate will also test its relevance for use in studies aimed at the combat of human disease. Several recent studies of the proteome of $M$. tuberculosis have been reported including the analysis of cell lysates, culture-filtrate proteins and the response of $M$. $t u$ berculosis to different environmental conditions (Lee \& Horwitz, 1995; Garbe et al., 1996, 1999; Sonnenberg \& Belisle, 1997; Urquhart et al., 1997, 1998; Weldingh et al., 1998; Wong et al., 1999). The most comprehensive study to date, in terms of protein spot identification, compared two strains of Mycobacterium bovis bacille Calmette-Guérin (BCG) and the M. tuberculosis strains H37Rv and Erdman (Jungblut et al., 1999). These data have been deposited in a database accessible via the internet (Mollenkopf et al., 1999; http://www.mpiibberlin.mpg.de/2D-PAGE/). Most recently, subcellular fractions of M. tuberculosis H37Rv have been analysed by two-dimensional (2D) PAGE and several proteins identified (Rosenkrands et al., 2000). These data are also available via the internet (http://www.ssi.dk/en/ forskning/tbimmun/tbhjemme.htm).

In this study we have compared the protein profiles of cell lysates of M. tuberculosis H37Rv and CDC 1551, utilizing commercially available immobilized $\mathrm{pH}$ gradients (IPGs) of $\mathrm{pH} 4-7$ and $\mathrm{pH} 3-10$ over a three point time course. We have been able to resolve approximately 1750 distinct protein spots and show that the protein profiles of these two strains remain remarkably similar. Proteins which were identified as being different between the strains or differed with time have been characterized by MS (reviewed by HumpherySmith et al., 1997). In addition, we have compared differences seen experimentally at the protein level to those predicted from comparison of the two genome sequences.

\section{METHODS}

Bacterial culture. M. tuberculosis H37Rv (NCTC 7416) and CDC 1551 (I. Orme, Colorado State University, USA) were grown without shaking in $10 \mathrm{ml}$ Middlebrook $7 \mathrm{H} 9$ media supplemented with $0 \cdot 2 \%(\mathrm{v} / \mathrm{v})$ glycerol, $10 \%$ albumindextrose-catalase (ADC) and $0.025 \%$ Tween 80 at $37{ }^{\circ} \mathrm{C}$. Optical densities at $550 \mathrm{~nm}$ were measured on a plate reader (Victor) using $200 \mu \mathrm{l}$ culture and adjusted for $1 \mathrm{~cm}$ path length.

Sample preparation for two-dimensional (2D) electrophoresis. Whole-cell extracts were prepared from $M$. tuberculosis by harvesting $2 \times 10 \mathrm{ml}$ culture for each strain after 5,8 and $12 \mathrm{~d}$ growth. Cultures were pooled and pelleted by centrifugation $(1900 \mathrm{~g}, 15 \mathrm{~min})$. Cell pellets were washed twice in PBS $/ 1 \%(\mathrm{v} / \mathrm{v})$ Tween 80 . Mycobacteria were resuspended in lysis buffer containing $0.3 \%(\mathrm{w} / \mathrm{v})$ SDS, $200 \mathrm{mM}$ DTT, $28 \mathrm{mM}$ Tris $/ \mathrm{HCl}, 22 \mathrm{mM}$ Tris base, $1 \mathrm{mM}$ PMSF and Complete protease inhibitor cocktail (Roche Molecular Biochemicals), and heat-killed at $80{ }^{\circ} \mathrm{C}$ for $20 \mathrm{~min}$ prior to bead disruption in a ribolyser (Hybaid). Lysates were then clarified by centrifugation and the supernatant removed. The protein concentration of each sample was estimated using the Bradford assay (Bradford, 1976).

2D electrophoresis. Isoelectric focusing sample loading buffer (8 M urea, 4\%, w/v, CHAPS, $40 \mathrm{mM}$ Tris base, $65 \mathrm{mM}$ DTT, trace amount of bromophenol blue) was added to the samples and each separated using $\mathrm{pH} \mathrm{4-7}$ and $\mathrm{pH}$ 3-10 (non-linear) $18 \mathrm{~cm}$ IPG strips (Amersham Pharmacia Biotech) in the first dimension. Total protein $(50 \mu \mathrm{g})$ was loaded at the cathode and proteins focused as follows using a Multiphor II (Amersham Pharmacia Biotech) : $300 \mathrm{~V}$ for $2 \mathrm{~h}, 1000 \mathrm{~V}$ for $1 \mathrm{~h}$ and $3500 \mathrm{~V}$ for $22 \mathrm{~h}$. Second-dimension electrophoresis was carried out essentially as described by O'Farrell (1975), using large format $(20 \times 20 \mathrm{~cm}), 1.5 \mathrm{~mm}$ thick, $12 \%$ polyacrylamide gels. IPG strips were equilibrated prior to running on the second dimension as described (Bjellqvist et al., 1993; http:// www.expasy.ch/ch2d/protocols/) but using 0.375 M Tris/ $\mathrm{HCl}, \mathrm{pH} 8 \cdot 8$, and 15 min incubation times. Strips were then overlaid onto the second-dimension gels and sealed with $0.5 \%$ $(\mathrm{w} / \mathrm{v})$ agarose in cathode buffer, containing a trace amount of bromophenol blue. Anode and cathode buffers as described by Herbert et al. (1998) were used. For protein spot comparisons, gels were silver stained using an ammoniacal stain as described (Bjellqvist et al., 1993; http://www.expasy.ch/ch2d/ protocols/). For subsequent MS, gels were rerun and silver stained as described by Shevchenko et al. (1996a) with some 
modifications (Betts \& Smith, 2000). Gel images were digitized by scanning on a flat-bed scanner (Epson GT9000).

Sample preparation for mass spectrometry. Protein spots of interest were excised from the gel, reduced, carboxyamidated and digested in situ with trypsin as described by Jensen et al. (1999). After digestion overnight at $37^{\circ} \mathrm{C}$, samples were centrifuged and an aliquot of the supernatant taken for analysis by MALDI (matrix-assisted laser desorption-ionization) MS. Prior to nanoelectrospray analysis, peptides were extracted from the gel pieces as described by Jensen et al. (1999).

MALDI-MS. This was performed on a VG TofSpec SE time-offlight (TOF) mass spectrometer equipped with a delayed extraction ion source (Micromass). Samples were prepared largely as described by Jensen et al. (1996). A saturated solution of $\alpha$-cyano-4-hydroxycinnamic acid in acetone was mixed in a $4: 1$ ratio $(\mathrm{v} / \mathrm{v})$ with a $10 \mathrm{~g} \mathrm{l}^{-1}$ solution of nitrocellulose (Trans-Blot transfer medium, $0.45 \mu \mathrm{m}$; Bio$\mathrm{Rad})$ in acetone/2-propanol $(1: 1, \mathrm{v} / \mathrm{v})$. This was deposited on the stainless steel target in $0.6 \mu$ laliquots, leaving a matrix/ nitrocellulose surface by fast evaporation of the solvent. Aliquots $(0.5 \mu \mathrm{l})$ were taken from the tryptic digest mixture and loaded into a $0.5 \mu \mathrm{l}$ droplet of $5 \%(\mathrm{v} / \mathrm{v})$ formic acid previously applied to the matrix. Samples were air dried at room temperature and washed with $1 \mu 15 \%(\mathrm{v} / \mathrm{v})$ formic acid prior to insertion into the instrument. Spectra were internally calibrated using the matrix ion at $\mathrm{m} / z$ 1060.10 and trypsin autolysis peaks at $m / z 2163.06$ and $m / z$ 2289.15. Monoisotopic masses were assigned and proteins identified by peptide mass fingerprinting using PepSea software (Protana) and a mass accuracy of $0 \cdot 1 \mathrm{Da}$.

Nanoelectrospray MS. Dried digest mixtures were desalted prior to nanoelectrospray analysis. Pulled glass capillaries were packed with approximately $5 \mu$ l POROS R2 sorbent (PerSeptive Biosystems). Peptides were dissolved in $0.5 \%$ $(\mathrm{v} / \mathrm{v})$ formic acid, loaded on to the sorbent and washed with $5 \mu \mathrm{l} 0.5 \% \quad(\mathrm{v} / \mathrm{v})$ formic acid. Samples were eluted with approximately $2 \mu \mathrm{l} 1 \%(\mathrm{v} / \mathrm{v})$ formic acid, $50 \%$ (v/v) methanol and $1 \mu \mathrm{l}$ inserted into the spraying needle. Needles for electrospraying were made with a micropipette puller (Sutter Instrument) from borosilicate glass capillaries (Clark Electromedical Instruments) as described by Wilm \& Mann (1994, 1996) and were gold coated in a vapour desorption instrument. Electrospray mass spectra were acquired on an API III triple quadrupole machine (Perkin-Elmer Sciex) equipped with a nanoelectrospray ion source (Wilm \& Mann, 1994, 1996). Proteins were identified by the sequence tag approach using PepSea software (Protana).

Genome comparison. The MUMmer program (Delcher et al., 1999) was used to align and compare the genome sequences of M. tuberculosis H37Rv and CDC 1551 using a MUMmer cut off of $50 \mathrm{bp}$. The genome sequences of H37Rv and CDC 1551 were downloaded from the Sanger Center, Hinxton, Cambridge, release date 17 June 1998 (http://www. sanger.ac.uk/Projects/M_tuberculosis/) and The Institute for Genome Research, release date 4 June 1999 (http://www. tigr.org/tdb/CMR/gmt/htmls/SplashPage.html), respectively.

\section{RESULTS}

\section{Comparison of 2D protein patterns of Mycobacterium tuberculosis strains H37Rv and CDC 1551}

Comparison of the protein patterns of $\mathrm{H} 37 \mathrm{Rv}$ and CDC 1551 were made at selected time points. Cultures of each

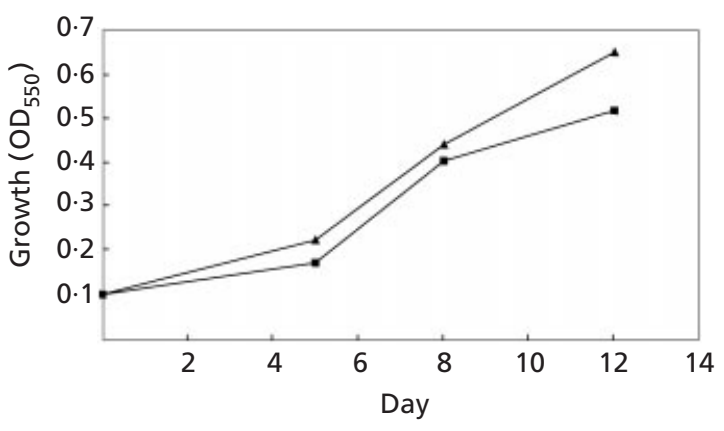

Fig. 1. Growth curves for M. tuberculosis H37Rv ( $\mathbf{\Delta}$ ) and CDC 1551 ( $\square$ ) over the time course studied.

strain were grown in duplicate and pooled for 2D electrophoretic analysis. Duplicate gels were run for each sample and silver stained. Care was taken to ensure that all gels were stained to the same extent; however, variability was seen amongst very faint spots just at the silver-stain detection limit. These spots were therefore excluded from our comparisons. For subsequent identification of protein spots, gels were rerun, again in duplicate, and stained with a silver stain compatible with mass spectrometry though less sensitive than the initial ammoniacal stain used. This also served to confirm the reproducibility of spot differences observed in the initial analysis. The differences detailed here were found to be consistent with both silver-staining protocols used. Fig. 1 shows that the growth of the two strains was similar up until day 8 . By day 12 , however, CDC 1551 seemed to be entering stationary phase whilst $\mathrm{H} 37 \mathrm{Rv}$ was still in late exponential phase. Despite this, the resulting protein spot patterns were found to be both highly reproducible and highly comparable between the two strains over all time points. The $2 \mathrm{D}$ protein patterns also varied little across the time course studied. Approximately 1500 protein spots were visualized on the $\mathrm{pH} 4-7$ gels and 1100 spots on the $\mathrm{pH} 3-10$ gels, with approximately 250 of these being unique to the $\mathrm{pH} 3-10$ range and hence giving a combined total of 1750 . Since the majority of proteins seemed to be in the acidic range, increased resolution of this area on the $\mathrm{pH} 4-7$ gels significantly aided individual spot resolution and comparison of protein species within this region. One $\mathrm{pH}$ 4-7 gel representative of each time point for each strain is shown in Fig. 2.

Table 1 summarizes the protein spot differences and proteins identified. Only consistent differences obvious by visual examination have been included. A total of 17 consistent protein spot differences were seen, comprising both differences between the two strains and common differences between the three time points. Gel regions displaying spot differences between the strains are surrounded by boxes on Fig. 2 and shown in more detail in Fig. 3. Protein spots differing with time of culture are numbered on Fig. 2. Seven protein spots (spots 1-7) seemed to be present only in CDC 1551 . Three spots (spots 8-10) seemed to be exclusive to $\mathrm{H} 37 \mathrm{Rv}$ and a 

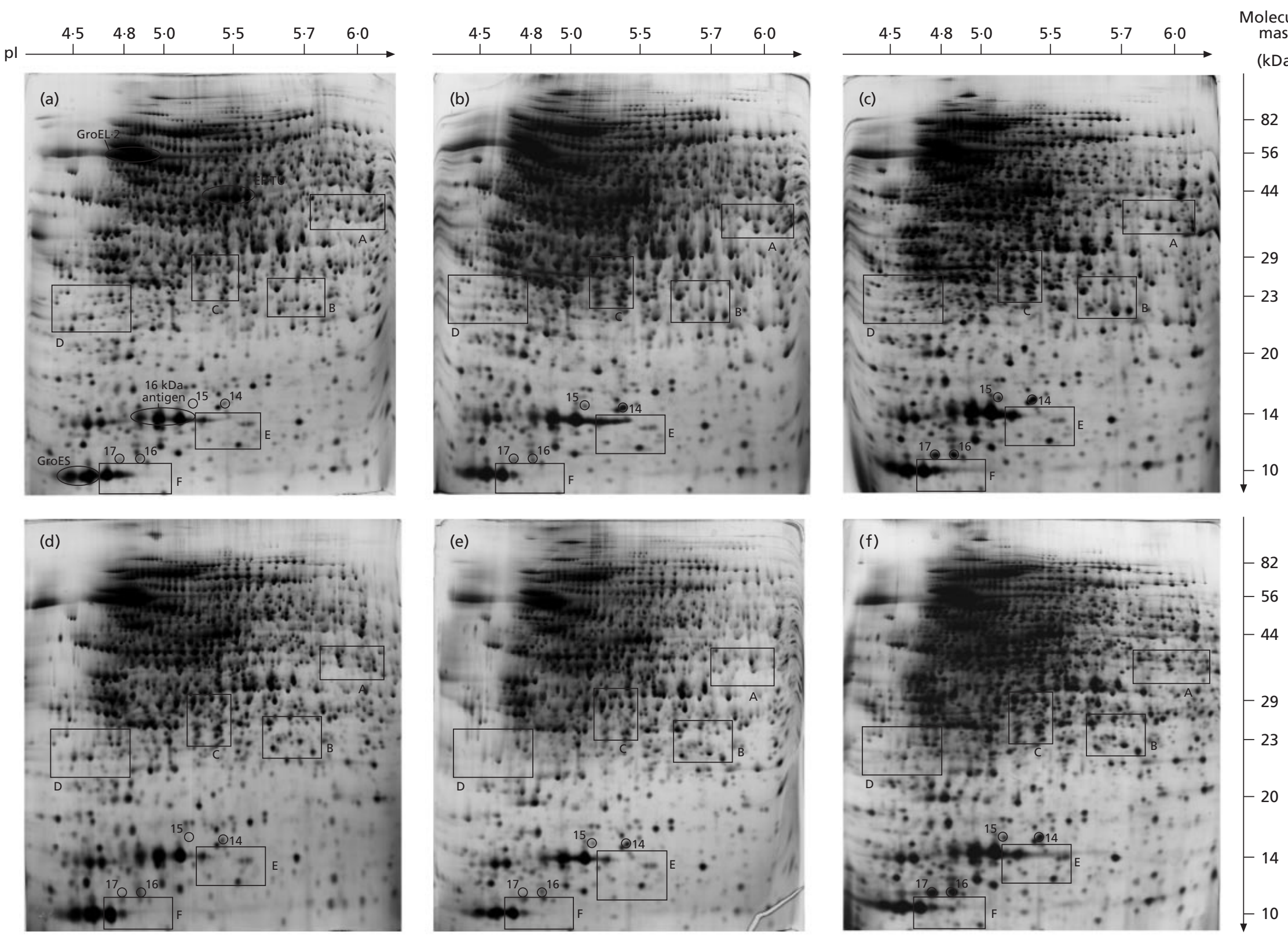

Fig. 2. 2D gels of $M$. tuberculosis over the three-point time course. (a) H37Rv, day 5; (b) H37Rv, day 8; (c) H37Rv, day 12; (d) CDC 1551, day 5; (e) CDC 1551, day 8; ( $f$ ) CDC 1551, day 12. Protein spots changing over the time course are ringed and their identities listed in Table 1 . Regions where protein spots differ between strains are surrounded by boxes (labelled A-F) and shown in detail in Fig. 3. Key landmark proteins previously identified by MS are marked on (a). 
Table 1. Protein spot differences observed for the time-point proteome analysis of $M$. tuberculosis $H 37 R v$ and CDC 1551

Spots not detected represented by - . Spots present represented by + . Increased spot intensity compared to other strain/time point represented by ++ . Vertical mobility shift represented by $\mathrm{M}$.

\begin{tabular}{|c|c|c|c|c|c|c|c|c|c|c|c|c|}
\hline \multirow[t]{2}{*}{$\begin{array}{c}\text { Spot } \\
\text { no. }\end{array}$} & \multirow[t]{2}{*}{ Protein } & \multirow[t]{2}{*}{$\begin{array}{l}\text { Short } \\
\text { name }\end{array}$} & \multirow[t]{2}{*}{ Rv no. } & \multirow[t]{2}{*}{ MT no. } & \multicolumn{2}{|c|}{$\begin{array}{l}\text { MALDI mass } \\
\text { mapping }\end{array}$} & \multirow[t]{2}{*}{$\begin{array}{l}\mathrm{H} 37 \mathrm{Rv} \\
\text { day } 5\end{array}$} & \multirow[t]{2}{*}{$\begin{array}{c}\text { H37Rv } \\
\text { day } 8\end{array}$} & \multirow[t]{2}{*}{$\begin{array}{l}\mathrm{H} 37 \mathrm{Rv} \\
\text { day } 12\end{array}$} & \multirow[t]{2}{*}{$\begin{array}{l}\text { CDC } 1551 \\
\text { day } 5\end{array}$} & \multirow[t]{2}{*}{$\begin{array}{l}\text { CDC } 1551 \\
\text { day } 8\end{array}$} & \multirow[t]{2}{*}{$\begin{array}{l}\text { CDC } 1551 \\
\text { day } 12\end{array}$} \\
\hline & & & & & $\begin{array}{c}\text { No. } \\
\text { matched } \\
\text { peptides }\end{array}$ & $\begin{array}{c}\text { Sequence } \\
\text { coverage } \\
(\%)\end{array}$ & & & & & & \\
\hline 1 & Probable alcohol dehydrogenase & - & Rv0927c & MT0954 & 4 & 16 & - & - & - & + & + & + \\
\hline 2 & Transcriptional regulator, MoxR homologue & MoxR & Rv1479 & MT1526 & 15 & 42 & - & - & - & + & + & + \\
\hline 3 & Transcriptional regulator, MoxR homologue & MoxR & Rv1479 & MT1526 & 20 & 63 & - & - & - & + & + & + \\
\hline 4 & Not identified & & & & & & - & - & - & + & + & + \\
\hline 5 & Not identified & & & & & & - & - & - & + & + & + \\
\hline 6 & Not identified & & & & & & - & - & - & + & + & + \\
\hline 7 & Not identified & & & & & & - & - & - & + & + & ++ \\
\hline 8 & Transcriptional regulator, MoxR homologue & MoxR & Rv1479 & MT1526 & 4 & 12 & + & + & + & - & - & - \\
\hline 9 & Transcriptional regulator, MoxR homologue & MoxR & Rv1479 & MT1526 & 13 & 45 & + & + & + & - & - & - \\
\hline 10 & $\begin{array}{l}\text { Phosphoribosylformimino- } 5 \text {-aminoimidazole } \\
\text { carboxamide ribonucleotide isomerase }\end{array}$ & HisA & Rv1603 & MT1639 & 3 & 22 & + & + & + & - & - & - \\
\hline 11 & Alkyl hydroperoxide reductase chain C & AhpC & Rv2428 & MT2503 & 12 & 79 & ++ & ++ & ++ & + & + & + \\
\hline 12 & Alkyl hydroperoxide reductase chain C & AhpC & Rv2428 & MT2503 & 4 & 31 & ++ & ++ & ++ & + & + & + \\
\hline 13 & Ribosome recycling factor & Rrf & Rv2882c & MT2949 & 7 & 51 & м & M & M & M & м & м \\
\hline 14 & Putative Hsp20 & - & Rv0251c & MT0265 & 5 & 47 & + & ++ & ++ & + & ++ & ++ \\
\hline 15 & Not identified & & & & & & + & ++ & ++ & + & ++ & ++ \\
\hline 16 & $16 \mathrm{kDa}$ antigen, $\alpha$-crystallin homologue & HspX & Rv2031c & MT2090 & 7 & 57 & + & + & ++ & + & + & ++ \\
\hline 17 & $16 \mathrm{kDa}$ antigen, $\alpha$-crystallin homologue & HspX & Rv2031c & MT2090 & 6 & 37 & + & + & ++ & + & + & ++ \\
\hline
\end{tabular}

further two (spots 11 and 12) were of increased intensity in $\mathrm{H} 37 \mathrm{Rv}$ relative to $\mathrm{CDC} 1551$. One spot (spot 13) showed differing vertical mobility between the two strains. Proteins were identified using a hierarchical approach (Shevchenko et al., 1996b), combining peptide mass fingerprinting (Henzel et al., 1993; James et al., 1993; Mann et al., 1993; Pappin et al., 1993; Yates et al., 1993) by MALDI-TOF MS as a rapid first-pass technique with tandem mass spectrometric sequencing by nanoelectrospray (Shevchenko et al., 1996a; Wilm et al., 1996) used for any protein spots remaining unidentified. Proteins identified were assigned the appropriate $\mathrm{Rv}$ numbers, relating to the $\mathrm{H} 37 \mathrm{Rv}$ genome (Cole et al., 1998), and corresponding MT numbers, relating to the CDC 1551 genome (http://www.tigr.org/tdb/CMR/ $\mathrm{gmt} / \mathrm{htmls} /$ SplashPage.html).

Of the 17 spots analysed, 12 were identified unambiguously by MALDI-MS alone. Details of the number of matched peptides and the percentage sequence coverage obtained for each protein spot are given in Table 1. Criteria used to determine a positive identification were at least three matching peptides with $0 \cdot 1 \mathrm{Da}$ mass accuracy. The $\mathrm{pI}$ and $M_{\mathrm{r}}$ of the identified protein were also checked against the spot position on the gel. Further analysis of the remaining spots by nanoelectrospray failed to give an identification. Mass spectrometry analysis of these differences revealed that four spots (2, 3, 8 and 9) (Fig. 3a) were mobility variants of the transcriptional regulator MoxR (Rv1479/ MT1526). These varied in their comparative presence at each position between the strains, with $\mathrm{H} 37 \mathrm{Rv}$ displaying two forms and CDC 1551 a different two, and may be explained by either amino acid changes or posttranslational modifications. The most intense form present in $\mathrm{H} 37 \mathrm{Rv}$ was observed in a more basic position on the gel relative to the most intense form present in CDC 1551. The other H37Rv spot corresponding to this protein was also in a more basic position than the second CDC 1551 spot. Mobility variants of this protein have also been observed between the strains H37Rv and Erdman (Jungblut et al., 1999), with the protein being shifted to a more acidic position in the Erdman strain. One spot, identified as ribosome recycling factor (Rv2882c/MT2949), showed a marked vertical mobility shift between the two strains, being consistently in a higher $M_{\mathrm{r}}$ position on the H37Rv gels (spot 13) (Fig. 3b). Spot 1 (Fig. 3b), corresponding to Rv0927c, a probable alcohol dehydrogenase, was absent from the H37Rv proteome, whilst spot 10 (Fig. 3d), corresponding to phosphoribosylformimino-5-aminoimidazole carboxamide ribonucleotide isomerase (HisA; Rv1603/ MT1639), was absent from the CDC 1551 proteome. Two spots corresponding to alkyl hydroperoxide reductase chain C (AhpC; Rv2428/MT2503) were identified and both were decreased in intensity in CDC 1551 (spots 11 and 12) (Fig. 3d). This protein has also been found to be decreased in intensity in $\mathrm{H} 37 \mathrm{Rv}$ relative to M. bovis BCG Chicago (Jungblut et al., 1999).

Four proteins (spots 14-17) showed increased intensity over time in both strains (Fig. 2). Spot 14 was identified as the heat-shock protein, Hsp20 (Rv0251c/MT0265) and showed increased spot intensity on days 8 and 12 compared to day 5 . Spots 16 and 17 were identified as the $16 \mathrm{kDa}$ antigen (alpha-crystallin) (Rv2031c/MT2031c) 
(a)

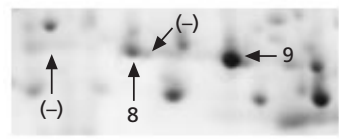

(b)

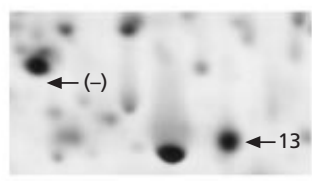

(c)

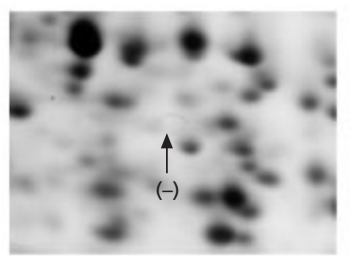

(d)

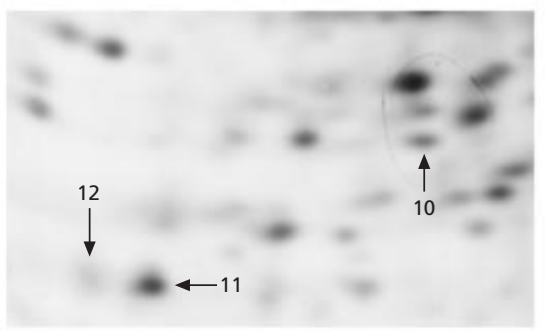

(e)
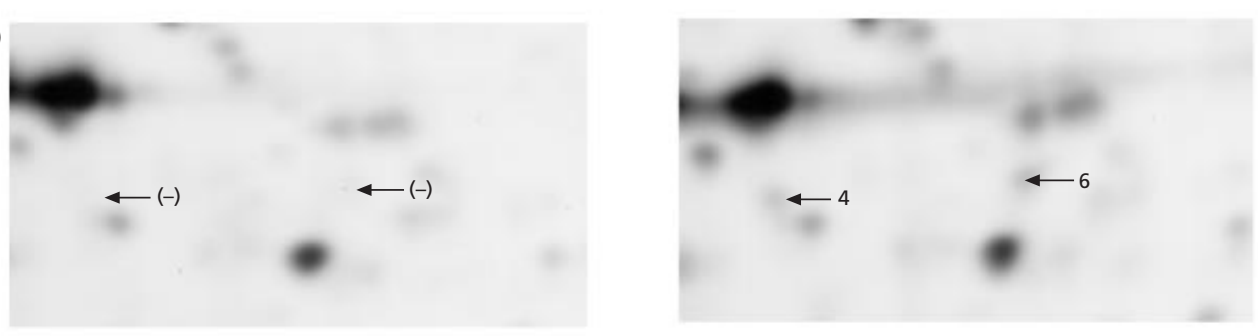

(f)

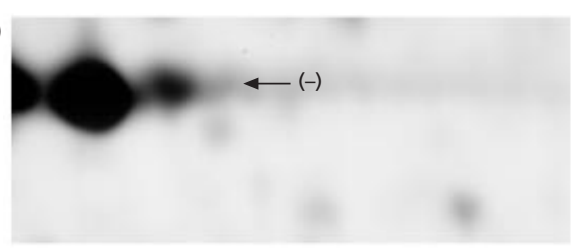

CDC 1551
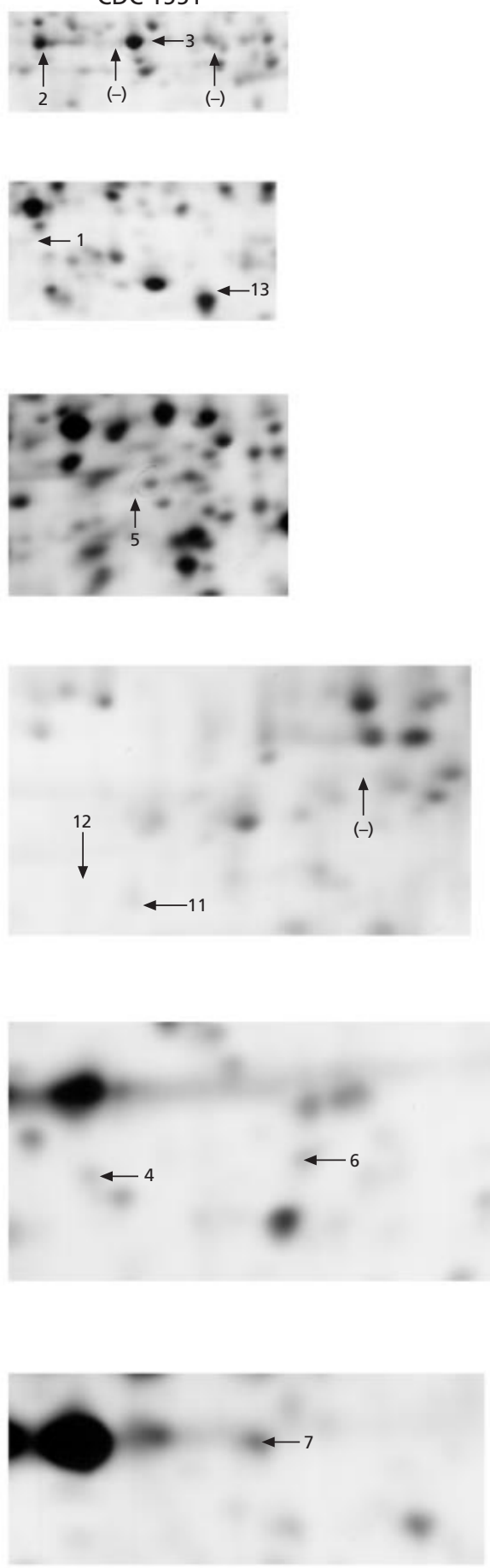

Fig. 3. Gel sections showing differences in protein spots detected between $M$. tuberculosis H37Rv and $\mathrm{CDC}$ 1551. Boxed regions (A-F) indicated on Fig. 2 are displayed in panels (a)-(f) respectively. Spot identities are listed in Table 1. and showed increased intensity on day 12 compared to days 5 and 8 .

\section{Comparison of proteome data with differences observed in the genomes of $M$. tuberculosis H37Rv and CDC 1551}

Comparison of the genome sequences of the two strains was carried out using the MUMmer program (Delcher et al., 1999). This enabled the mapping of single nucleotide changes and insertions and deletions present in each genome relative to the other. The majority of differences were found to be single nucleotide changes. Approximately 1000 of these were identified. One of the observed proteome differences correlates with a single nucleotide change. This occurs in the moxR gene (Rv1479/MT1526), where there is a base change from C in $\mathrm{H} 37 \mathrm{Rv}$ to $\mathrm{A}$ in CDC 1551, resulting in a predicted 
Table 2. Predicted protein differences resulting from genomic sequence present in H37Rv but not CDC 1551

\begin{tabular}{|c|c|c|c|c|c|c|c|c|c|}
\hline \multicolumn{2}{|c|}{ Genome position" } & \multirow[t]{2}{*}{ Size (bp) } & \multirow[t]{2}{*}{ Rv no. } & \multirow[t]{2}{*}{$M_{\mathrm{r}} \dagger$} & \multirow[t]{2}{*}{$\mathrm{pI} \dagger$} & \multirow[t]{2}{*}{ MT no. } & \multirow[t]{2}{*}{$M_{\mathrm{r}} \dagger$} & \multirow[t]{2}{*}{$\mathrm{pI} \dagger$} & \multirow[t]{2}{*}{ Protein $\neq$} \\
\hline Start & End & & & & & & & & \\
\hline $\begin{array}{l}32351 \\
32720\end{array}$ & $\begin{array}{l}32388 \\
32725\end{array}$ & $\left.{ }_{4}^{37}\right\}$ & Rv0029 & 39559 & $7 \cdot 88$ & МТ0033 & 17082 & $9 \cdot 02$ & Conserved hypothetical \\
\hline 183857 & 183861 & 3 & Rv0155 & 37693 & $4 \cdot 90$ & - & - & - & Transhydrogenase alpha subunit \\
\hline 333547 & 339002 & $\left.{ }^{5452}\right\}$ & Rv0278c & 81904 & $11 \cdot 16$ & - & - & - & PE-PGRS \\
\hline 427358 & 427373 & 15 & Rv0355c & 327030 & $4 \cdot 11$ & мТ0370 & 324564 & $4 \cdot 11$ & PPE \\
\hline \multirow[t]{4}{*}{836082} & \multirow[t]{4}{*}{840993} & \multirow[t]{4}{*}{4910 ? } & Rv0745 & 18648 & $11 \cdot 53$ & МТ0772 & 28088 & $11 \cdot 53$ & Conserved hypothetical \\
\hline & & & $\mathrm{Rv} 0746$ & 64158 & 3.97 & - & - & - & PE-PGRS \\
\hline & & & Rv0747 & 65407 & $4 \cdot 43$ & - & - & - & PE-PGRS \\
\hline & & & Rv0748 & 9114 & $9 \cdot 92$ & МТ0772 & 28088 & $11 \cdot 53$ & Conserved hypothetical \\
\hline \multirow[t]{3}{*}{886543} & \multirow[t]{3}{*}{887417} & \multirow[t]{3}{*}{874} & Rv0792c & 28959 & $8 \cdot 54$ & MT0817 & 67988 & 6.38 & GntR transcriptional regulator \\
\hline & & & Rv0793 & 11192 & $5 \cdot 61$ & - & - & - & Conserved hypothetical \\
\hline & & & Rv0794c & 52476 & $5 \cdot 61$ & MT0817 & 67988 & 6.38 & Dihydrolipoamide dehydrogenase \\
\hline 1212121 & 1212199 & 78 & Rv1087 & 62469 & $4 \cdot 18$ & - & - & - & PE-PGRS \\
\hline 1217504 & 1218158 & 58 & Rv1091 & 68317 & 4.19 & MT1123 & 51726 & $4 \cdot 02$ & PE-PGRS \\
\hline 2163788 & 2163926 & 138 & Rv1917c & 140612 & 3.75 & MT1968 & 146131 & $3 \cdot 84$ & PPE \\
\hline 2165426 & 2165502 & $76\}$ & & & & & & & \\
\hline 2180804 & 2180826 & 22 & Rv1928c & 27031 & $5 \cdot 46$ & - & - & - & Short-chain alcohol dehydrogenase \\
\hline \multirow[t]{2}{*}{2357283} & \multirow[t]{2}{*}{2357286} & \multirow{2}{*}{$3\}$} & Rv2098c & 36529 & $4 \cdot 34 \lambda$ & MT2159 & 41978 & $4 \cdot 33$ & PE-PGRS \\
\hline & & & Rv2099c & 5510 & $4 \cdot 32 \boldsymbol{J}$ & & & & \\
\hline 2372491 & 2372548 & 57 & Rv2112c & 60129 & $5 \cdot 70$ & MT2172 & 58256 & $5 \cdot 47$ & Conserved hypothetical \\
\hline 2714308 & 2714808 & 500 & Rv2416c & 44418 & 5.97 & MT2489 & 51387 & $6 \cdot 37$ & Conserved hypothetical \\
\hline 3054718 & 3054931 & 213 & Rv2741 & 44210 & $4 \cdot 40$ & MT2812 & 43562 & $5 \cdot 56$ & PE-PGRS \\
\hline 3171570 & 3171624 & 54 & $\operatorname{Rv} 2859 \mathrm{c}$ & 32410 & $5 \cdot 39$ & MT2927 & 32684 & $5 \cdot 86$ & Conserved hypothetical \\
\hline 3663929 & 3663992 & 63 & Rv3281 & 19014 & $4 \cdot 48$ & MT3380 & 16887 & $4 \cdot 54$ & Conserved hypothetical \\
\hline \multirow[t]{2}{*}{3730578} & \multirow[t]{2}{*}{3735861} & \multirow[t]{2}{*}{5283} & \multirow[t]{2}{*}{ Rv3343c } & \multirow{2}{*}{250346} & \multirow[t]{2}{*}{$4 \cdot 09$} & f MT3446 & 34947 & 5.94 & PPE \\
\hline & & & & & & МТ3447 & 56229 & 6.89 & \\
\hline 3739705 & 3739894 & 189 & Rv3345c & 129385 & $9 \cdot 58$ & MT3449 & 126768 & $9 \cdot 52$ & PE-PGRS \\
\hline 3933523 & 3936659 & 3136 & Rv3508 & 147625 & $3 \cdot 70$ & MT6312 & 194124 & $10 \cdot 08$ & PE-PGRS \\
\hline \multirow[t]{2}{*}{3955465} & 3956104 & 639 ? & Rv3518c & 44399 & $4 \cdot 70$ & MT3619 & 41439 & 4.72 & Cytochrome P450 \\
\hline & & & Rv3519 & 25960 & $9 \cdot 66$ & MT3620 & 7827 & $10 \cdot 81$ & Unknown \\
\hline 4359144 & 4359163 & $19\}$ & Rv3879c & 74492 & $5 \cdot 33$ & MT3993 & 73908 & $5 \cdot 33$ & Unknown \\
\hline
\end{tabular}

* Genome position of genomic sequence present in H37Rv but not CDC 1551.

† Predicted $M_{\mathrm{r}}$ and pI values calculated from the Expasy compute pI/Mw tool web site (http://www.expasy.ch/tools/pi_tool.html). $\ddagger$ Annotations taken from the TubercuList web site, Institute Pasteur (http://genolist.pasteur.fr/TubercuList/).

amino acid change from histidine- 26 in $\mathrm{H} 37 \mathrm{Rv}$ to asparagine-26 in CDC 1551 and consequently differences in the predicted $\mathrm{pI}$ and $M_{\mathrm{r}}$ values of the two proteins. This point mutation is contained within the $\mathrm{N}$-terminal tryptic peptide of the protein. However, this peptide was not mapped during the MALDI analysis to confirm the amino acid change. This can be explained by the fact that the peptide, minus the first methionine residue, has a calculated $M_{\mathrm{r}}$ of $4123.94 \mathrm{Da}$ or $4101.91 \mathrm{Da}$ for H37Rv or CDC 1551 respectively, meaning that it falls outside the range scanned during our MALDI analysis, as we routinely only cover a range up to $m / z 4000$. The predicted pI value (http://www.expasy.ch/tools/pi_ tool.html) for the H37Rv protein is 5.96 and that for the CDC 1551 protein is $5 \cdot 89$. This is reflected in the $2 \mathrm{D}$ gel spot pattern, where the major MoxR spot in H37Rv (spot 9) was shifted to a more basic position relative to the major CDC 1551 MoxR spot (spot 3) (Fig. 3a). This doesn't however explain the presence of a second form of MoxR in each strain, which could be caused by posttranslational modification. The predicted $M_{\mathrm{r}}$ values for the two proteins are $40762 \mathrm{Da}$ and $40739 \mathrm{Da}$ for $\mathrm{H} 37 \mathrm{Rv}$ and CDC 1551 respectively. The resolution of the gel in the $M_{r}$ range is not sufficient for this difference to be observed. It is also interesting to note that, although not containing a single nucleotide change itself, the his A gene (Rv1603/MT1639) lies directly downstream of hisH (Rv1602/MT1638), which contains a single nucleotide change resulting in an amino acid difference at the $\mathrm{C}$ terminus of the protein. We have shown a spot corresponding to HisA to be absent from the CDC 1551 proteome but present in the $\mathrm{H} 37 \mathrm{Rv}$ proteome.

Insertions or deletions in the genome which result in predicted $\mathrm{pI}$ or $M_{\mathrm{r}}$ differences at the protein level between the two strains are summarized in Tables 2 and 3 . We have limited our comparison to regions which appeared to be unique to each genome and were at least 3 bp in size. Insertion elements differing between the two strains have not been included in Tables 2 and 3. The majority of unique coding material found only in the H37Rv genome, with respect to CDC 1551, affected insertion elements or the acidic, glycine-rich proteins of the PE (Pro-Glu) and PPE (Pro-Pro-Glu) protein families which often contain multiple copies of the polymorphic $\mathrm{G}+\mathrm{C}$ rich sequences (PGRSs) or major polymorphic tandem repeats, respectively (Cole et al., 1998). Our analysis found eight ORFs completely unique to $\mathrm{H} 37 \mathrm{Rv}$, five of these belonging to the PE-PGRS family (Rv0278c, Rv0279c, Rv0746, Rv0747 and Rv1087) and one being a 
Table 3. Predicted protein differences resulting from genomic sequence present in CDC 1551 but not H37Rv

\begin{tabular}{|c|c|c|c|c|c|c|c|c|c|}
\hline \multicolumn{2}{|c|}{ Genome position" } & \multirow[t]{2}{*}{ Size (bp) } & \multirow[t]{2}{*}{ Mt no. } & \multirow[t]{2}{*}{$M_{\mathrm{r}} \dagger$} & \multirow[t]{2}{*}{$\mathrm{pI} \dagger$} & \multirow[t]{2}{*}{ Rv no. } & \multirow[t]{2}{*}{$M_{\mathrm{r}} \dagger$} & \multirow[t]{2}{*}{$\mathrm{pI} \dagger$} & \multirow[t]{2}{*}{ Protein $\neq$} \\
\hline Start & End & & & & & & & & \\
\hline 150883 & 151063 & 180 & MT0132 & 46525 & $5 \cdot 04$ & Rv0124 & 40891 & 4.90 & PE-PGRS \\
\hline 477981 & 479339 & 1358 & МТ0415 & 16135 & $6 \cdot 27$ & Rv0403c & 15261 & 6.64 & Small membrane protein \\
\hline 619256 & 619340 & 84 & MT0556 & 49170 & $4 \cdot 17$ & Rv0532 & 50835 & $4 \cdot 39$ & PE-PGRS \\
\hline 1111473 & 1111488 & 15 & MT1033 & 40686 & 6.07 & Rv1004c & 38754 & 4.78 & Possible exported protein \\
\hline 1432687 & 1432743 & 56 & MT1328 & 54536 & $9 \cdot 13$ & Rv1290c & 55996 & $9 \cdot 42$ & Unknown \\
\hline 1470228 & 1471902 & $1674\}$ & $\begin{array}{l}\text { MT1360 } \\
\text { MT1361 }\end{array}$ & $\begin{array}{l}57889 \\
60720\end{array}$ & $\left.\begin{array}{l}9.59 \\
9.76\end{array}\right\}$ & Rv1319c & 58098 & $9 \cdot 79$ & Possible adenylate cyclase \\
\hline 1601854 & 1601860 & 6 & MT1478 & 4820 & 4.79 & Rv1434 & 4606 & $5 \cdot 09$ & Unknown \\
\hline 1602221 & 1602242 & 21 & MT1479 & 20494 & $5 \cdot 02$ & Rv1435c & 18488 & $4 \cdot 10$ & Hypothetical conserved \\
\hline 1874909 & 1874919 & 10 & MT1707 & 65021 & $6 \cdot 21$ & Rv1668c & 40339 & $9 \cdot 57$ & Probable $\mathrm{ABC}$ transporter \\
\hline 1963756 & 1963916 & 160 & MT1796 & 109674 & $4 \cdot 16$ & Rv1753c & 104650 & $4 \cdot 16$ & PPE \\
\hline \multirow[t]{4}{*}{1968420} & \multirow[t]{4}{*}{1975229} & \multirow[t]{4}{*}{6809} & MT1799 & 57066 & $6 \cdot 35$ & Rv1755c & 29970 & $7 \cdot 13$ & Phospholipase C \\
\hline & & & MT1800 & 41288 & $10 \cdot 04$ & - & - & - & Glycosyl transferase \\
\hline & & & MT1801 & 40756 & $4 \cdot 90$ & - & - & - & Oxidoreductase \\
\hline & & & MT1802 & 99509 & $6 \cdot 62$ & - & - & - & Membrane protein \\
\hline \multirow[t]{2}{*}{2120399} & \multirow[t]{2}{*}{2120414} & \multirow[t]{2}{*}{15} & \multirow[t]{2}{*}{ MT1931 } & \multirow{2}{*}{48900} & \multirow[t]{2}{*}{$\int 8 \cdot 10$} & Rv1882c & 30010 & $9 \cdot 61$ & Probable dehydrogenase \\
\hline & & & & & & Rv1883c & 17281 & $8 \cdot 71$ & Conserved hypothetical \\
\hline 2150367 & 2150634 & 276 & MT1968 & 146131 & $3 \cdot 84$ & Rv1917c & 140612 & 3.75 & PPE \\
\hline \multirow[t]{3}{*}{2255757} & \multirow[t]{3}{*}{2260757} & $5000)$ & MT2080 & 26192 & 8.89 & - & - & - & Conserved hypothetical \\
\hline & & & MT2081 & 34444 & $8 \cdot 18$ & - & - & - & Conserved hypothetical \\
\hline & & & MT2082 & 177866 & $5 \cdot 48$ & Rv2024c & 57274 & $5 \cdot 65$ & Conserved hypothetical \\
\hline 2619675 & 2621718 & 2043 & MT2420 & 10000 & $4 \cdot 97$ & - & - & - & Conserved hypothetical \\
\hline & & & MT2421 & 11778 & 4.98 & - & - & - & Conserved hypothetical \\
\hline & & & MT2422 & 40092 & $4 \cdot 50$ & - & - & - & PPE \\
\hline & & & MT2423 & 59491 & $4 \cdot 05$ & Rv2353c & 34069 & $4 \cdot 22$ & PPE \\
\hline 2852392 & 2853048 & $656)$ & MT2619 & 27086 & $6 \cdot 19$ & - & - & - & Putative lipoprotein \\
\hline & & & MT2620 & 27112 & $5 \cdot 96$ & Rv2544 & 24175 & $6 \cdot 19$ & Putative lipoprotein \\
\hline 2980704 & 2980806 & 102 & MT2754 & 31680 & $4 \cdot 47$ & Rv2680 & 22555 & $4 \cdot 51$ & Conserved hypothetical \\
\hline 3361395 & 3362754 & 1359 & МТ3098 & 12334 & $4 \cdot 24 \lambda$ & Rv3018c & 42997 & $4 \cdot 08$ & PPE \\
\hline & & & MT3101 & 31983 & $4 \cdot 17\}$ & & & & \\
\hline 3514231 & 3516381 & 2150 & MT3247 & 57661 & $4 \cdot 19)$ & $\operatorname{Rv} 3159 \mathrm{c}$ & 56586 & $4 \cdot 22$ & PPE \\
\hline & & & MT3248 & 66937 & $4.51\}$ & & & & \\
\hline 4022344 & 4022455 & 111 & MT3715 & 29829 & $12 \cdot 00$ & Rv3611 & 23815 & $11 \cdot 93$ & Unknown \\
\hline
\end{tabular}

*Genome position of genomic sequence present in CDC 1551 but not H37Rv.

†Predicted $M_{\mathrm{r}}$ and $\mathrm{pI}$ values calculated from the Expasy compute $\mathrm{pI} / \mathrm{Mw}$ tool web site (http://www.expasy.ch/tools/pi_tool.html). ‡Annotations taken from the TubercuList web site, Institute Pasteur (http://genolist.pasteur.fr/TubercuList/) or from the TIGR M. tuberculosis genome database (http://www.tigr.org/tdb/CMR/gmt/htmls/SplashPage.html) for ORFs unique to CDC 1551.

hypothetical protein (Rv0793). Rv0278c and Rv0279c are contained within a $5452 \mathrm{bp}$ region which is missing from CDC 1551. Similarly, Rv0746 and Rv0747 are contained within a $4910 \mathrm{bp}$ region which is deleted in CDC 1551 relative to H37Rv. Part of Rv0748 is also contained within this deleted region. As a result of this large deletion the ORF predictions in this region differ between the two strains. Rv0745 is present at the DNA level in CDC 1551; however, the corresponding ORF in CDC 1551 (MT0772) has a different predicted start site and is frame-shifted. MT0772 is predicted to span the deleted region and its $\mathrm{C}$ terminus corresponds to that of Rv0748. Deletions in CDC 1551 in the region of the remaining two ORFs (Rv0155 and Rv1928c) seem to result in frameshifts, producing numerous stop codons, which are likely to mean that these regions are noncoding in CDC 1551.

The CDC 1551 genome seems to contain nine unique ORFs. Eight of these are contained within three separate large deletions from H37Rv. MT1800-MT1802 lie within a 6809 bp stretch of DNA which is absent from $\mathrm{H} 37 \mathrm{Rv}$. This region corresponds to RvD2 which has been found to be deleted in $\mathrm{H} 37 \mathrm{Rv}$ with respect to $M$. bovis and M. bovis BCG (Gordon et al., 1999), and also the attenuated M. tuberculosis strain H37Ra (Brosch et al., 1999). MT1800 is annotated as a glycosyl transferase and a BLASTP search of a non-redundant protein database showed it to have significant similarity to sugar transferases and proteins involved in lipopolysaccharide biosynthesis. MT1801 is annotated as an oxidoreductase and shows considerable homology to eukaryotic sulphite oxidase genes. MT1802 is annotated as a membrane protein belonging to the $\mathrm{MmpL}$ family. This region also contains MT1799, which is a full-length version of phospholipase $C$ ( $p l c D$ gene) that is interrupted by an IS6110 insertion in H37Rv (Rv1755c). MT2080 and MT2081 are both annotated as hypothetical and lie within a $5000 \mathrm{bp}$ region deleted in $\mathrm{H} 37 \mathrm{Rv}$ relative to CDC 1551. This region is also present in $M$. bovis and M. bovis BCG (Gordon et al., 1999). MT2082, also in this region, is an extended version of the H37Rv gene Rv2024c which bears homology to a hypothetical protein from Helicobacter pylori (TrEMBL accession no. O25380). MT2420-MT2422 are contained within a $2043 \mathrm{bp}$ region deleted from H37Rv. Eight further genes in this region have been found to be deleted in M. bovis and M. bovis BCG (Behr et al., 1999; Gordon et al., 
1999). All three ORFs are annotated as hypothetical; however, MT2420 shows homology to proteins of the ESAT-6 family (Berthet et al., 1998; Tekaia et al., 1999). Immediately upstream is MT2421 which shows $95 \%$ identity with the QILSS family of proteins, so called because of a distinctive QILSS motif at the C terminus. In the M. tuberculosis H37Rv genome this family consists of six members all of which occur upstream of ESAT-6 ORFs (Tekaia et al., 1999). MT2422 shows a high level of homology to MT2419/Rv2352c, which encodes a PPE protein. Upstream of this region in the $\mathrm{H} 37 \mathrm{Rv}$ sequence are two ORFs (Rv2354 and Rv2355) not present in CDC 1551, which code for a transposase of an IS6110 insertion element. This seems to have disrupted the gene immediately upstream (Rv2353c) which corresponds to $5^{\prime}$ truncation of MT2423.

The remaining predicted protein differences between the two strains are the result of small insertions or deletions at the DNA level, giving significant changes in predicted $M_{\mathrm{r}}$ and $\mathrm{pI}$ at the protein level. None of the protein spot differences observed in this study correspond to predicted changes resulting from these insertions or deletions. However, it is possible that the four remaining unidentified proteins correspond to some of these predicted protein differences.

\section{DISCUSSION}

The availability of genome sequence data for two virulent strains of M. tuberculosis (Cole et al., 1998; http://www.tigr.org/tdb/CMR/gmt/htmls/SplashPage. html) has facilitated the study of the proteome of this organism. Here we describe the comparison of the proteome of these two strains, a lab strain $(\mathrm{H} 37 \mathrm{Rv})$ and a recent clinical isolate (CDC 1551). After its outbreak in 1995, initial reports suggested that CDC 1551 was a highly virulent strain of $M$. tuberculosis based on the high rate of skin-test conversion in contacts to the index case, the unusually large PPD (purified protein derivative of tuberculin) reactions observed and its increased growth in mice compared to M. tuberculosis Erdman (Valway et al., 1998). Due to serial passage and, more importantly, its unknown virulence in humans, concerns have been raised as to the relevance of M. tuberculosis $\mathrm{H} 37 \mathrm{Rv}$ as a model for the study of human disease (Jacobs et al., 1996). More recently both in vivo and in vitro models have been used to compare the growth of, and host response to, M. tuberculosis CDC 1551, $\mathrm{H} 37 \mathrm{Rv}$, Erdman and two other clinical isolates (Manca et al., 1999). This study led to the conclusion that CDC 1551 is not more virulent than other strains of M. tuberculosis but induces a more vigorous host response.

In our proteome comparison of these strains, it was hoped that any protein differences seen may give some insight into the reasons for the differing phenotypes observed, aiding the design of new drugs and vaccines against tuberculosis. Additionally, these studies provide a useful background reference for future proteome experiments and, in comparing its protein profile to that of a recent clinical isolate, test the relevance of H37Rv as a model for human infection.

Strains were compared over a three-point time course. This is an important precursor to further proteome analyses. The protein patterns of the two strains were stable and highly similar over the time course studied. Only 13 protein spots were seen to differ between the two strains. This is consistent with the comparison of M. tuberculosis H37Rv and Erdman, which revealed 18 variant proteins (Jungblut et al., 1999). Four of the variants described here correspond to different mobility variants of the MoxR protein, which is a probable regulatory protein involved in the formation of active methanol dehydrogenase. Mobility variants of MoxR were also observed in the comparison of $\mathrm{H} 37 \mathrm{Rv}$ with Erdman (Jungblut et al., 1999). Genome sequence comparison of the moxR gene in H37Rv and CDC 1551 revealed a single nucleotide change, resulting in a predicted amino acid difference and consequent pI change, explaining the presence of mobility variants of this protein. The M. tuberculosis Erdman genome has not been sequenced. However, in the light of our findings, it is likely that the mobility variants of MoxR, described by Jungblut et al. (1999), are also a result of a single nucleotide change, and hence amino acid difference, in this protein between H37Rv and Erdman. A spot corresponding to Rv0927c/MT0954, a probable short-chain alcohol dehydrogenase, was found to be present on gels of CDC 1551 but not H37Rv. The gene encoding this protein is, however, present in the H37Rv genome. Similarly, a spot corresponding to HisA, an isomerase which catalyses the fourth step in the histidine biosynthetic pathway, was present on gels of H37Rv but not CDC 1551, although the corresponding gene is present in the CDC 1551 genome. The his $A$ gene forms part of an operon of histidine biosynthetic genes. The levels of the other proteins encoded within this operon, however, were not detected as differences in this study. These differences are most likely to be explained either by subtle expression-level differences between the two strains at the point in time studied, meaning that the absent protein spots are present but below the silver-stain detection limit, by post-translational modification or by degradation during sample preparation. Interestingly, $\mathrm{AhpC}$ was found to be increased in intensity in $\mathrm{H} 37 \mathrm{Rv}$ relative to CDC 1551 . This protein has also been found to be increased in intensity in $M$. bovis BCG compared to M. tuberculosis $\mathrm{H} 37 \mathrm{Rv}$ (Jungblut et al., 1999).

The protein profile of each strain also seemed similar across the three time points studied, with only a small number of protein spots changing in intensity with time. Two of these were identified as the $16 \mathrm{kDa}$ antigen $(\alpha-$ crystallin), which has been shown to be upregulated as the bacterium enters stationary phase (Yuan et al., 1996). However, this protein is also found as an intense spot higher up the gel (Fig. 2a) so it is likely that these spots are due to degradation or post-translational processing. This observation has been made previously 
(Sonnenberg \& Belisle, 1997), where lower molecular mass spots were found to correspond to N-terminal truncation or degradation by Edman sequencing. The intensity of the spot representing the main form of this protein does however seem to be increased somewhat on day 12 relative to days 5 and 8 . Another heat-shock protein, Hsp20, also shows increased intensity on days 8 and 12 in both strains.

Of the differences that we have identified in this proteome comparison, only those in the MoxR protein relate to those predicted from the genome comparison. There are several explanations for this discrepancy. Firstly, some of the proteins predicted to differ between strains lie outside the region resolved on our $2 \mathrm{D}$ gels; that is a $M_{\mathrm{r}}$ above $100 \mathrm{kDa}$ or below $10 \mathrm{kDa}$, or a $\mathrm{pI}$ above $10 \cdot 0$. Secondly, we have resolved approximately 1750 protein spots. At best this accounts for $44 \%$ of the 3924 predicted genes in M. tuberculosis H37Rv. However, some spots visualized here appear to be spot series of the same protein, perhaps caused by amino acid modifications during sample preparation. Whilst it is extremely unlikely that all predicted proteins are expressed at the same point in time, it is likely that certain lowabundance proteins are masked by the more abundant species on our gels, particularly in the acidic region where the majority of mycobacterial proteins seem to lie, or are below the detection limit of silver staining. It has been suggested that proteins present at less than 1000 copies per cell cannot currently be detected by 2D electrophoresis (Wilkins et al., 1998). The limitations of silver staining must also be considered. Although the ammoniacal method utilized for comparison purposes here is extremely sensitive and care was taken to ensure equal intensity of gel staining, variation between protein spots at the silver-stain detection limit was observed and these low-level differences were not included in our comparison. The dynamic range of silver staining is also limited and certain proteins have been shown to stain poorly or not at all. Fluorescent stains, compatible with MS, have recently been developed and now approach the sensitivity of silver staining whilst overcoming the issues of dynamic range and reproducibility.

Some of the proteins predicted to differ are membrane proteins and it is very likely that these hydrophobic proteins are underrepresented on our gels as standard 2D techniques, such as those used in our study, often result in substantial losses of hydrophobic proteins due to solubility problems during sample preparation, precipitation in the first-dimension IPG or inefficient transfer to the second-dimension gel (Adessi et al., 1997; Wilkins et al., 1998). There have recently been a number of methods reported which improve protein solubilization in 2D electrophoresis (Rabilloud et al., 1997; Herbert et al., 1998; Molloy et al., 1998; Santoni et al., 1999). Such methods are likely to be required in order to visualize more of the mycobacterial proteome. To this end, it may also be necessary to study subcellular fractions of $M$. tuberculosis as described recently by Rosenkrands et al. (2000). Another approach may be to utilize several overlapping narrow-pH-range IPGs to build up a composite proteome map and increase spot resolution (Cordwell et al., 2000).

Lastly, many of the predicted differences are within PE or PPE genes, for which there is little functional information available and it is still unclear as to whether they are all expressed and at what level. The recently published mycobacterial 2D PAGE internet database, which contains information on approximately 260 proteins identified from 2D gels of M. tuberculosis and M. bovis BCG by MS, does not include any PE or PPE proteins (Mollenkopf et al., 1999; http://www.mpiibberlin.mpg.de/2D-PAGE/) However, inspection of the amino acid sequence of many of these proteins reveals them to have few trypsin cleavage sites. This would make identification by MS following tryptic digestion, as routinely used, almost impossible. Since the PE and PPE families of proteins have been implicated in antigenic variation in M. tuberculosis (Cole et al., 1998), it is interesting to speculate that the variation in these proteins between the two strains may be significant with regard to their differing immunogenic properties (Manca et al., 1999).

The genome comparison also reveals that CDC 1551 contains an extra gene (MT2420) that bears homology to the ESAT-6 family. The ESAT-6 protein is a major Tcell antigen which has been purified from M. tuberculosis culture filtrates (Sorensen et al., 1995) and is recognized strongly by a high percentage of tuberculosis patients (Mustafa et al., 1998; Ulrichs et al., 1998; Ravn et al., 1999). More recently, two further members of this family have been identified within culture filtrates and shown to induce interferon gamma release from lymphocytes isolated from tuberculosis patients (Skjøt et al., 2000). There are 14 members of the ESAT- 6 family within H37Rv and all are situated in genomic loci showing strongly conserved structure and organization (Tekaia et al., 1999). Each of these genes are conserved in CDC 1551. It is possible that the extra copy of this gene in CDC 1551 may contribute to the increased host immune response to this strain (Manca et al., 1999). Our study was focused on the analysis of cellular proteins. It is likely that an analysis of the culture filtrate would be required to reveal differences in the secreted antigens such as the ESAT-6 family of proteins. Our current studies are now directed toward the analysis of membrane and secreted proteins from M. tuberculosis.

Of the 17 silver-stained spots analysed here, 12 were identified by MALDI-MS alone giving a success rate of about $70 \%$. The availability of the complete genome sequence of $M$. tuberculosis means that, in theory, it should be possible to identify the majority of proteins by peptide mass fingerprinting using the MALDI data alone. We have used a protein loading of approximately $50 \mu \mathrm{g}$ for our analyses and pooled spots from duplicate gels. The protein spots which remain unidentified are low in abundance as judged by the silver-stain intensity and it is therefore likely to be advantageous to increase protein loading on gels for subsequent mass spectrometry analysis. Another alternative is to use HPLC 
combined with tandem mass spectrometry (LC/ MS/MS) for the analysis of these protein spots. We have recently found this method to have increased sensitivity over the nanoelectrospray technique employed in this study (unpublished results).

In conclusion, we have performed a rigorous proteome comparison of two virulent strains of $M$. tuberculosis for which there is genome sequence available. The proteome patterns of the two strains grown in broth are highly similar which is in accordance with their high sequence similarity. This suggests that M. tuberculosis $\mathrm{H} 37 \mathrm{Rv}$ is indeed a valid laboratory model for the study of the mechanisms of human disease. To gain more insight into the differing phenotypes displayed by these two strains it may be necessary to perform proteome analysis on mycobacteria isolated from conditions where these phenotypes are observed; for example macrophages or animal models of infection. In contrast to the genome level, differences seen at the proteome level are likely to reflect variability in translational control and post-translational modification between the strains. Despite the limitations discussed here, 2D gelbased proteomics remains a powerful approach toward the functional understanding of the proteins encoded within the mycobacterial genome. Technologies are constantly being improved and the problems associated with $2 \mathrm{D}$ gels are being eliminated. This study provides a useful and necessary background reference for future studies where the genes responsible for virulence, intracellular survival or drug resistance may be identified through the analysis of mutant strains or mycobacteria subjected to differing environmental conditions. In turn, this may provide us with targets for the development of novel therapies against tuberculosis.

\section{REFERENCES}

Adessi, C., Miege, C., Albrieux, C. \& Rabilloud, T. (1997). Twodimensional electrophoresis of membrane proteins: a current challenge for immobilized $\mathrm{pH}$ gradients. Electrophoresis 18, 127-135.

Behr, M. A., Wilson, M. A., Gill, W. P., Salamon, H., Schoolnik, G. K., Rane, S. \& Small, P. M. (1999). Comparative genomics of BCG vaccines by whole-genome DNA microarray. Science 284, $1520-1523$.

Berthet, F.-X., Rasmussen, P. B., Rosenkrands, I., Andersen, P. \& Gicquel, B. (1998). A Mycobacterium tuberculosis operon encoding ESAT-6 and a novel low-molecular-mass culture filtrate antigen. Microbiology 144, 3195-3203.

Betts, J. C. \& Smith, M. A. (2000). Proteomics. In Mycobacterium tuberculosis Protocols, Methods in Microbiology. In press. Edited by T. Parish \& N. G. Stoker. Totowa, NJ: Humana.

Bishai, W. R., Dannenberg, A. M., Jr., Parrish, N., Ruiz, R., Chen, P., Zook, B. C., Johnson, W., Boles, J. W. \& Pitt, M. L. (1999). Virulence of Mycobacterium tuberculosis CDC 1551 and H37Rv in rabbits evaluated by Lurie's pulmonary tubercle count method. Infect Immun 67, 4931-4934.

Bjellqvist, B., Pasquali, Ch., Ravier, F., Sanchez, J.-Ch. \& Hochstrasser, D. F. (1993). A nonlinear wide-range immobilized $\mathrm{pH}$ gradient for two-dimensional electrophoresis and its definition in a relevant pH scale. Electrophoresis 14, 1357-1365.
Bradford, M. (1976). A rapid and sensitive method for the quantitation of microgram quantities of protein utilizing the principle of protein-dye binding. Anal Biochem 72, 248-254.

Brosch, R., Philipp, W. J., Stavropoulos, E., Colston, M. J., Cole, S. T. \& Gordon, S. V. (1999). Genomic analysis reveals variation between Mycobacterium tuberculosis H37Rv and the attenuated M. tuberculosis H37Ra strain. Infect Immun 67, 5768-5774.

Cole, S. T., Brosch, R., Parkhill, J. \& 39 other authors (1998). Deciphering the biology of Mycobacterium tuberculosis from the complete genome sequence. Nature 393, 537-544.

Cordwell, S. J., Nouwens, A. S., Verrills, N. M., Basseal, D. J. \& Walsh, B. J. (2000). Subproteomics based upon protein cellular location and relative solubilities in conjunction with composite two-dimensional electrophoresis gels. Electrophoresis 21, 1094-1103.

Delcher, A. L., Kasi, S., Fleischmann, R. D., Peterson, J., White, O. \& Salzberg, S. L. (1999). Alignment of whole genomes. Nucleic Acids Res 27, 2369-2376.

Garbe, T. R., Hibler, N. S. \& Deretic, V. (1996). Response of Mycobacterium tuberculosis to reactive oxygen and nitrogen intermediates. Mol Med 2, 134-142.

Garbe, T. R., Hibler, N. S. \& Deretic, V. (1999). Response to reactive nitrogen intermediates in Mycobacterium tuberculosis: induction of the 16-kilodalton $\alpha$-crystallin homolog by exposure to nitric oxide donors. Infect Immun 67, 460-465.

Gordon, S. V., Brosch, R., Billault, A., Garnier, T., Eiglmeier, K. \& Cole, S. T. (1999). Identification of variable regions in the genomes of tubercle bacilli using bacterial artificial chromosome arrays. Mol Microbiol 32, 643-655.

Henzel, W. J., Billeci, T. M., Stults, J. T. \& Wong, S. C. (1993). Identifying proteins from two-dimensional gels by molecular mass searching of peptide fragments in protein sequence databases. Proc Natl Acad Sci US A 90, 5011-5015.

Herbert, B. R., Molloy, M. P., Gooley, A. A., Walsh, B. J., Bryson, W. G. \& Williams, K. L. (1998). Improved protein solubility in twodimensional electrophoresis using tributyl phosphine as reducing agent. Electrophoresis 19, 845-851.

Humphery-Smith, I., Cordwell, S. J. \& Blackstock, W. P. (1997). Proteome research: complementarity and limitations with respect to the RNA and DNA-worlds. Electrophoresis 18, 1217-1242.

Jacobs, W., Brennan, P., Curlin, G. \& 10 other authors (1996). Comparative sequencing. Science 274, 17-18.

James, P., Quadroni, M., Carafoli, E. \& Gonnet, G. (1993). Protein identification by mass profile fingerprinting. Biochem Biophys Res Commun 195, 58-64.

Jensen, O. N., Podtelejnikov, A. \& Mann, M. (1996).Delayed extraction improves specificity in database searches by matrixassisted laser desorption/ionisation peptide maps. Rapid Commun Mass Spectrom 10, 1371-1378.

Jensen, O. N., Wilm, M., Shevchenko, A. \& Mann, M. (1999). Sample preparation methods for mass spectrometric peptide mapping directly from 2-DE gels. Methods Mol Biol 112, 513-530.

Jungblut, P. R., Schaible, U. E., Mollenkopf, H. \& 7 other authors (1999). Comparative proteome analysis of Mycobacterium tuberculosis and Mycobacterium bovis BCG strains: towards functional genomics of microbial pathogens. Mol Microbiol 33, 1103-1117.

Lee, B. Y. \& Horwitz, M. A. (1995). Identification of macrophage and stress-induced proteins of Mycobacterium tuberculosis. J Clin Invest 96, 245-249.

Manca, C., Tsenova, L., Barry, C. E., III, Bergtold, A., Freeman, S., Haslett, P. A., Musser, J. M., Freedman, V. H. \& Kaplan, G. (1999). 
Mycobacterium tuberculosis CDC 1551 induces a more vigorous host response in vivo and in vitro, but is not more virulent than other clinical isolates. J Immunol 162, 6740-6746.

Mann, M., Hojrup, P. \& Roepstorff, P. (1993). Use of mass spectrometric molecular weight information to identify proteins in sequence databases. Biol Mass Spectrom 22, 338-345.

Mollenkopf, H. J., Jungblut, P. R., Raupach, B., Mattow, J., Lamer, S., Zimny-Arndt, U., Schaible, U. E. \& Kaufmann, S. H. (1999). A dynamic two-dimensional polyacrylamide gel electrophoresis database: the mycobacterial proteome via Internet. Electrophoresis 20, 2172-2180.

Molloy, M. P., Herbert, B. R., Walsh, B. J., Tyler, M. I., Traini, M., Sanchez, J. C., Hochstrasser, D. F., Williams, K. L. \& Gooley, A. A. (1998). Extraction of membrane proteins by differential solubilization for separation using two-dimensional gel electrophoresis. Electrophoresis 19, 837-844.

Mustafa, A. S., Amoudy, H. A., Wiker, H. G., Abal, A. T., Ravn, P., Oftung, F. \& Anderson, P. (1998). Comparison of antigen specific $T$ cell responses of tuberculosis patients using complex or single antigens of Mycobacterium tuberculosis. Scand J Immunol 48, 535-543.

O’Farrell, P. H. (1975). High resolution two-dimensional electrophoresis of proteins. J Biol Chem 250, 4007-4021.

Pappin, D., Hojrup, P. \& Bleasby, A. J. (1993). Rapid identification of proteins by peptide-mass fingerprinting. Curr Biol 3, 327-332.

Rabilloud, T., Adessi, C., Giraudel, A. \& Lunardi, J. (1997). Improvement of the solubilization of proteins in two-dimensional electrophoresis with immobilized $\mathrm{pH}$ gradients. Electrophoresis 18, 307-316.

Ravn, P., Demissie, A., Eguale, T. \& 11 other authors (1999). Human $\mathrm{T}$ cell responses to the ESAT- 6 antigen secreted from Mycobacterium tuberculosis. J Infect Dis 179, 637-645.

Rosenkrands, I., Weldingh, K., Jacobsen, S., Hansen, C. V., Florio, W., Gianetri, I. \& Andersen, P. (2000). Mapping and identification of Mycobacterium tuberculosis proteins by two-dimensional gel electrophoresis, microsequencing and immunodetection. Electrophoresis 21, 935-948.

Santoni, V., Rabilloud, T., Doumas, P., Rouquie, D., Mansion, M., Kieffer, S., Garin, J. \& Rossignol, M. (1999). Towards the recovery of hydrophobic proteins on two-dimensional electrophoresis gels. Electrophoresis 20, 705-711.

Shevchenko, A., Wilm, M., Vorm, O. \& Mann, M. (1996a). Mass spectrometric sequencing of proteins from silver-stained polyacrylamide gels. Anal Chem 68, 850-858.

Shevchenko, A., Jensen, O. N., Podtelejnikov, A. V. \& 7 other authors (1996b). Linking genome and proteome by mass spectrometry: large-scale identification of yeast proteins from two dimensional gels. Proc Natl Acad Sci U S A 93, 14440-14445.

Skjøt, R. L. V., Oettinger, T., Rosenkrands, I., Ravn, P., Brock, I., Jacobsen, S. \& Andersen, P. (2000). Comparative evaluation of low-molecular-mass proteins from Mycobacterium tuberculosis identifies members of the ESAT- 6 family as immunodominant Tcell antigens. Infect Immun 68, 214-220.

Sonnenberg, M. G. \& Belisle, J. T. (1997). Definition of Mycobacterium tuberculosis culture filtrate proteins by twodimensional polyacrylamide gel electrophoresis, N-terminal amino acid sequencing, and electrospray mass spectrometry. Infect Immun 65, 4515-4524.
Sorensen, A. L., Nagai, S., Houen, G., Andersen, P. \& Andersen, A. B. (1995). Purification and characterization of a low-molecularmass T-cell antigen secreted by Mycobacterium tuberculosis. Infect Immun 63, 1710-1717.

Tekaia, F., Gordon, S. V., Garnier, T., Brosch, R., Barrell, B. G. \& Cole, S. T. (1999). Analysis of the proteome of Mycobacterium tuberculosis in silico. Tuber Lung Dis 79, 329-342.

Ulrichs, T., Munk, M. E., Mollenkopf, H., Behr-Perst, S., Colangeli, R., Gennaro, M. L. \& Kaufmann, S. H. (1998). Differential T cell responses to Mycobacterium tuberculosis ESAT-6 in tuberculosis patients and healthy donors. Eur J Immunol 28, 3949-3958.

Urquhart, B. L., Atsalos, T. E., Roach, D., Basseal, D. J., Bjellqvist, B., Britton, W. L. \& Humphery-Smith, I. (1997). 'Proteomic contigs' of Mycobacterium tuberculosis and Mycobacterium bovis (BCG) using novel immobilised $\mathrm{pH}$ gradients. Electrophoresis 18, 1384-1392.

Urquhart, B. L., Cordwell, S. J. \& Humphery-Smith, I. (1998). Comparison of predicted and observed properties of proteins encoded in the genome of Mycobacterium tuberculosis H37Rv. Biochem Biophys Res Commun 253, 70-79.

Valway, S. E., Sanchez, M. P., Shinnick, T. F., Orme, I., Agerton, T., Hoy, D., Jones, J. S., Westmoreland, H. \& Onorato, I. M. (1998). An outbreak involving extensive transmission of a virulent strain of Mycobacterium tuberculosis. N Engl J Med 338, 633-639.

Weldingh, K., Rosenkrands, I., Jacobsen, S., Rasmussen, P. B., Elhay, M. J. \& Andersen, P. (1998). Two-dimensional electrophoresis for analysis of Mycobacterium tuberculosis culture filtrate and purification and characterization of six novel proteins. Infect Immun 66, 3492-3500.

Wilkins, M. R., Gasteiger, E., Sanchez, J. C., Bairoch, A. \& Hochstrasser, D. F. (1998). Two-dimensional gel electrophoresis for proteome projects: the effects of protein hydrophobicity and copy number. Electrophoresis 19, 1501-1505.

Wilm, M. \& Mann, M. (1994). Electrospray and taylor-cone theory: Dole's beam of macromolecules at last? Int J Mass Spectrom Ion Proc 136, 167-180.

Wilm, M. \& Mann, M. (1996). Analytical properties of the nanoelectrospray ion source. Anal Chem 68, 1-8.

Wilm, M., Shevchenko, A., Houthaeve, T., Breit, S., Schweigerer, L., Fotsis, T. \& Mann, M. (1996). Femtomole sequencing of proteins from polyacrylamide gels by nanoelectrospray mass spectrometry. Nature 379, 466-469.

Wong, D. K., Lee, B. Y., Horwitz, M. A. \& Gibson, B. W. (1999). Identification of Fur, aconitase, and other proteins expressed by Mycobacterium tuberculosis under conditions of low and high concentrations of iron by combined two-dimensional gel electrophoresis and mass spectrometry. Infect Immun 67, 327-336.

Yates, J. R., III, Speicher, S., Griffin, P. R. \& Hunkapiller, T. (1993). Peptide mass maps: a highly informative approach to protein identification. Anal Biochem 214, 397-408.

Yuan, Y., Crane, D. D. \& Barry, C. E., III (1996). Stationary phaseassociated protein expression in Mycobacterium tuberculosis: function of the mycobacterial $\alpha$-crystallin homolog. J Bacteriol 178, 4484-4492.

Received 14 March 2000; revised 5 June 2000; accepted 19 August 2000. 